\title{
LAUDATIO
}

\section{IN HONOUR OF DISTINGUISHED PROFESSOR GAIL KLIGMAN, UNIVERSITY OF CALIFORNIA, LOS ANGELES, ON THE OCCASION OF BEING AWARDED THE DOCTOR HONORIS CAUSA TITLE OF THE BABEŞ-BOLYAI UNIVERSITY CLUJ-NAPOCA ${ }^{1}$}

\begin{abstract}
MARIUS LAZĂR ${ }^{2}$
Pro-rector David, President of the Academic Senate Chirilă, honored colleagues, and dear guests, friends, and students:
\end{abstract}

It so happens that I am giving this laudatio towards the end of a semester when I teach a course on the History of Romanian Social Thought, in which I discuss the stages of thinking and the main accomplishments of the most remarkable Romanian sociologists. In the last lectures, I come to speak about the development of sociology in the years after the political changes of 1989 and I necessarily refer to the contributions of the numerous foreign researchers who have produced substantial studies from and about Romania.

Their studies are already social documents. Their reports on the state of the Romanian society in the communist period, shared with the wider Romanian public only after 1989 , are even more important for having been written under very particular circumstances, when autochthonous research was either repressed or distorted by censorship or self-censorship. These studies are embraced by the Romanian colleagues who salute in them an honest and objective reflection of the country under the communist regime observed by these professional witnesses. These analyses save the honour of the profession, partly lost and then partly regained after 1989, notably due to the essential contribution of these researchers. In a wider perspective, they continue along the lines of the Romanian sociological tradition and its production from even before 1945 - the field research of the Sociological School of Bucharest, of Gh. Em. Marica in Cluj and of others, work that has become today a collection of documents of an era and of the manner in which this era was able to gaze upon itself. All these

\footnotetext{
1 Translated from Romanian by Raluca Perneș.

2 Sociology Department, Babeș-Bolyai University Cluj-Napoca, email: mlazar59@yahoo.com.
} 
foreign researchers have eventually gone native in more than one way. First, they have learnt to speak Romanian almost perfectly. As a side note, the anthropologists who have learnt Romanian in the rural areas where they did fieldwork acquired and adopted an idiom that is genuine, lacking in garishness, able to bypass disgraceful neologisms, a language to which Romanian intellectuals remain deaf. Then, they have learnt to feel along with the locals they have studied. Finally, they ended up being adopted locally as fictive kin members of their host families.

We are here today to celebrate one of these researchers. It is a great honour for me to be here and have the opportunity to profess Gail Kligman's organic connection with the most outstanding social research on Romania. In this she is accompanied by the works of other researchers such as Katherine Verdery, David Kideckel, Steven Sampson, or Claude Karnoouh.

Gail Kligman holds a BA in sociology (1971), an MA in folklore (1973), and a PhD in sociology (1977), all from University of California, Berkley. She has had a prodigious scientific career, rewarded with many awards, and is currently Distinguished Professor in the Sociology department of UCLA, Associate Vice Provost of the International Institute and was, between 20052015, Director of the UCLA Centre for European and Eurasian Studies.

Most of her research career is related to fieldwork in Romania, which she started in 1975. She first came here with an IREX scholarship, to conduct research for her PhD thesis on the ritual of căluș. Based on this, she has published the book Căluș: Symbolic Transformation in Romanian Ritual, which first appeared in 1981 with a preface by Mircea Eliade. The following year, the book was awarded the Chicago Folklore Prize by the American Folklore Society and the University of Chicago.

In 1978-1979, Gail Kligman returned to Romania for 13 months of postdoctoral research and settled in Ieud, a village that soon enough adopted the young American. It eventually became her privileged research site; in 1998, she also became honorary citizen of Ieud, a recognition she was so honoured about that she lists it in her CV alongside the multiple awards and titles she has been granted throughout her career. In Ieud, under the tutelage of the Institute for Ethnography and Folklore of the Romanian Academy and in constant collaboration with Prof. Mihai Pop, Gail Kligman started looking at oral poetry in the context of wedding rituals and that of funeral rituals for those who died young. But she was to go way beyond the routine folklore approach of the era, which was in the habit of separating the folkloric text from its bearers and its social context, and ended up producing a thorough monograph of the village and its transformations in the times of the 'multilaterally developed socialism'. Her analysis allows for an understanding of traditional poetry as a living form of social interaction and direct communication, in the context of everyday life, which was often a form of symbolic resistance to the constraints of the political regime as well. 
Thus, a researcher with a background in sociology and training as a folklorist ended up in an atypical research situation, in a location that was 'exotic' as related to her own society - communist Eastern Europe and Romania in particular were to the Americans, at that time, from many points of view, uncharted territory. It was a journey that was to make her into an anthropologist. The author then crossed over the dogmatic but arbitrarily built borders between the fields of sociology and anthropology, to affirm - closer to the original project of the founding fathers of both disciplines - the basic unity of the social sciences, based on their shared methodologies. Her second book, The Wedding of the Dead: Ritual, Poetics, and Popular Culture in Transylvania, 1988, followed the symbolic anthropological approach inaugurated by Călus, but the latter was decidedly closer to a critical social anthropology perspective than to a culturalist angle. In 1990, the book was to bring Gail Kligman another award, American Romanian Academy of Arts and Sciences Book Award.

The fall of Ceaussescu's regime in 1989 and the transformation of the Eastern European societies made it possible for Gail Kligman to become one of the recognized voices capable to present and explain to the American public the meaning of the changes in Romania, often through the means of conference presentations and papers with an immediate impact. Her research interest switched for this time on mainly to the sensitive aspects of these changes, such as the heightened interethnic tensions or the rearrangement of gender relations and the redefinition of feminine identity in the post-socialist world. Together with Susan Gal, she has written a book, The Politics of Gender After Socialism: A Comparative-Historical Essay (2000) and co-edited another, Reproducing Gender: Politics, Publics, and Everyday Life after Socialism (2000). Both have become landmarks and bona fide textbooks for those working on related topics in Romania.

The focal point of her interest in this period was the reflection on the politics of reproduction and on the consequences of the various laws regulating abortion in the contemporary society. The Romanian experience pushed Gail Kligman to go back, in order to unearth meanings, to the period before 1989. From the description of Ceaușescu's pronatalist demographic policies and their inhuman consequences, she pieced together a solid case against the coercive control of fertility and against the attempts of conservative politicians and groups to restrain women's rights to use and protect their bodies as they see fit. The result was one of Gail Kligman's strongest and most engaged books, The Politics of Duplicity: Controlling Reproduction in Ceausescu's Romania (1998), once again based on solid field research and data analysis.

It must be noted that the book's impact in Romania was extensive, especially after being translated in 2001. It provided arguments for feminist debates, as well as deepened the conversation about the legacy of Ceaușescu's regime and its moral culpability. Moreover, as far as the author's sociological 
outlook is concerned, this book marks the moment, already anticipated by the previous studies, of a crystallization of an ethnography of the state and of the manner in which state policies embed in the everyday lives of the citizens.

The books published in these period prompted yet another wave of recognition from important academic fora: in 1998, Gail Kligman received the Heldt Prize of the American Association for the Advancement of Slavic Studies for the best book in women's studies for The Politics of Duplicity; and in 2001, together with Susan Gal, another Heldt Prize of the Association for Women in Slavic Studies for the best book in Slavic/East European/Eurasian Women's Studies for The Politics of Gender After Socialism: A Comparative-Historical Essay. Her great accomplishments commended Gail Kligman as one of the most competent scholars of Romanian communism, propelling her in 2006 into the college for the coordination of the researchers of the Presidential Advisory Committee for the Study of the Romanian Communist Dictatorship (the Tismăneanu Commission).

At the height of her career, Gail Kligman was immersed in a new project about the process of collectivization, with her long term friend and collaborator Katherine Verdery. The research involved an impressive number of young investigators, most of them from Romania and two of them - Călin Goina and Virgil Țârău - our colleagues from Babeș-Bolyai University. Alongside their team, Kligman and Verdery conducted fieldwork and examined archives and other official and unofficial sources over the course of 13 years - exactly the duration of the collectivization process, that is. The end result was the most impressive reconstitution of this process that has transformed radically the economic structure and the social texture of the villages in Romania. The substantial volume Peasants under Siege: Collectivization in Romania, 1949-1962 (Princeton University Press, 2011) has been rewarded in 2012 with an impressive string of awards: Barbara Jelavich Prize for Distinguished Monograph, of the Association for Slavic, East European, and Eurasian Studies; Davis Center Book Prize in Political and Social Studies, of the Association for Slavic, East European, and Eurasian Studies; and two Honorable Mentions of the American Sociology Association: The Barrington Moore Best Book Award in Comparative-Historical Sociology, and Best Book Award, Political Sociology Section. The book was translated in Romanian in 2015 and published by Polirom. Its full impact is yet to come, but I am sure it will produce a thorough re-evaluation of the perspective on the period before 1989, one that will necessarily have to become more nuanced, closer to the context of everyday life and more methodologically complex.

We are therefore looking at a thematic trajectory that moves, in a spiral, from the symbolic and social anthropology of traditional poetics towards identity and gender politics; and then from the sociology of postcommunism to that of communism. A round trip journey. A to and fro motion, in which the amounts of personal time and objective history accumulated 
meets the way of thinking required by the anthropological fieldwork, which is often fragmentary and here-and-now. Personal biography, objective history, the microhistories of the explored communities, even the history of the community of researchers that study and redefine the object of their study on the one hand, and the grand scale history on the other hand - all of these engender a reflexive outlook on the world. Within the canon of the discipline, this takes on the form of an ethnography of the state and of an historical anthropology of communism, unmatched in the Eastern European space.

Despite the diversity of their themes, Gail Kligman's books are connected by an unremitting reflection on politics and modernity in the socialist and postsocialist era. Over the course of decades of research, they paint a vivid picture of the social processes characteristic of Eastern Europe in the decades before and after 1989. They also provide a critical reflection that is often at odds with the mainstream tide of opinion and with the stereotypical thinking it generates when it comes to understanding the transformation of the region.

The ethnographic perspective on the state addresses it simultaneously as an institutional organization producing ideologues and policies on the one hand and as a generator of social discourse on the other hand. The trademarks of the author's critical voice are the emphasis of the permanent conjunction of discourses, everyday practices and the wider social and political contexts shaping them; the exquisite understanding of the complexities and ambiguities of the mundane social interactions of the social actors; and the way in which these interactions are moulded by the context and generate in their turn new meanings for the discursive practices and actions associated with those practices. Almost every study of Gail Kligman manifests an utter acuity in grasping the subtlest shifts in meaning and the extremely innovative, sophisticated strategies for social communication of the social actors, in addition to the precise conceptual map and the excellent situation in context of the subject of the analysis; both are marks of her personal academic style as well as of her method. Gail Kligman operates, in a very particular and creative manner, with the pragmatics of the social discourse in which she brings together the individuals' strategies, positions, and mechanisms of demarcation in the social field with the manner in which they are articulated discursively. All of these together impregnate the rhetoric of the language in the social practices, incorporating them as an integral part of of their actions and not as an illustrative ornament. The distinctive trademark of Gail Kligman's complex way of describing the world of social relationships is perhaps best understood by looking at her dual experience as a folklorist and as a social researcher, a background she incorporates and mobilizes in an organic manner.

She has a non-manichaeist perspective on the communist era and identifies the complicated stances of the social actors and of the regime itself, 
stances based on embracing some pragmatic compromises, which also allow for some forms of resistance on the part of the subjects of the socialist state's policies.

The point of departure for the reflection on the distortions of the structures of sociability produced by the regime in the Romanian society is the very experience of duplicity as a mundane strategy for survival. This is not just about duplicity that manifests itself 'horizontally' amongst the regular folk, in their everyday interactions - a type of duplicity that erodes mutual trust as a fundament of the social. The former is generated by a 'vertical' duplicity, which operates in both directions. There is first of all a duplicity from above, which is brought about by the discrepancy between the principles that legitimize the discourse of the Party-State and the 'compromises' that the agents of the state need to make in order to put these policies into practice. These compromises themselves generate a web of more or less culpable complicities between the subjects of the state and the agents implementing state domination. Thus, the communist state can no longer be perceived as a machine that acts by inexorably levelling society, as it was designed to do. The state is also not an impersonal entity, even though it represents itself as such as a means to consolidate its authority; it is instead embodied into the actual persons acting in its name and producing their own interpretation of the tasks that need to be completed. These are people who often need to employ noncanonical means and actions to complete their assignments. This is the very phenomenon that eventually produces duplicity from below, that is to say the duplicity of the subjects of the social policies, who will seek spaces for regroupment and refuge in their personal lives, enacting the separation of the private sphere from the public sphere that had been fully confiscated by the state. They will also elude as much as possible the demands of the agents of etatization. Participation in the state policies is therefore ambiguous and fragmentary, combining the political conformism demanded by the state with the social conformism of the subjects of the sphere as of yet not completely confiscated by the politics of the regime. These subjects still act freely, in accordance with the sociability and honourability norms from before the intervention of the state. As such, everyday duplicity is the expression of the conflict between the norms that legitimize state intervention in the social life and the customs of non-state social reproduction of the subjects.

There is too little time to give due credit to the whole scientific contribution and to the merits of an exemplary endeavour. There are, however, two other aspects of Gail Kligman's work that need to be acknowledged.

One has to do with the transmission of a critical understanding of the transformations that took place in our society and in the contemporary world. Through her brave approach and its ethical implications, Gail Kligman has contributed substantially to a general shift in the attitudes of the intellectual milieus in Romania over the last years, which have generally become more open 
to supporting vulnerable groups: those marginalized on economic or social criteria, those discriminated on the basis of race, gender, and sexual orientation. But these circles are still insufficiently influential to counteract the domination of the neoconservative spirit, ready to denounce 'multiculturalism' and what they dismissively refer to as the 'principles of political correctness', in a society that has not yet had the chance to practice them on a large scale.

A second aspect has to do with her direct contribution to the reprofessionalization of the social sciences in Romania. She has actively supported the reconnection of the research in the field of the social sciences in Romania to the western and more specifically American paradigms of thinking that are currently active and influential, thus contributing to giving an opportunity to contemporary Romanian social researchers to compete as equals with their counterparts in other countries, in the context of a globalized scientific market. This would probably have also happened with Romanian sociology in the interwar period through the Sociological School of Bucharest of Dimitrie Gusti and his disciples were it not for the start of World War I.

The social sciences in Romania comprise a fortunate exception to a structural condition that produces delays in other fields. Let me explain myself: in modern Romania, intellectuals were always connected to the sources of knowledge provided by western thinking, from about mid-19th century up until mid-20th century, when the tradition has been broken by the installation of the communist regime. That is to say, intellectuals were moulded or influenced by stints in the western universities, where they adopted the paradigms of knowledge that were dominant in the era. It was a process of assimilating mainstream learning that was then transferred onto the researcher's initial scientific environment. Traditional Romanian academic culture has been coagulated around the activity and all-encompassing prestige of some illustrious personalities, such as Maiorescu and Iorga, to give but two examples. There has been no field of knowledge built on the basis of competition between equals and as a consequence, aside from the adoption of western models of research, there was a lag manifested in the attachment to some paradigms that, even in their place of origin, in their 'centre' of scientific influence, were soon made obsolete by the avant-garde researches that were moulding the new patterns of knowledge. This process led to the reproduction of a disparity between a more dynamic 'centre' and a 'periphery' that it lags behind, often times over the span of one or two generations, fixed in the old ways of scientific practice. The 'peripheries' are thus engaged in a willing 'auto-colonizing' effort as far as the products of scientific work are concerned, yet are stuck in a state of dependency through their inability to also adopt the competitive model of scientific production and the competitive environment in which this production takes place. They import products, but do not import means to produce them and so perpetuate at a cognitive level what Balandier describes as 'the colonial condition'. 
'The colonial condition' in the field of social research has been redefined and challenged in two ways by the arrival in Romania of researchers such as Kligman, Verdery, or Kideckel. First, the contact between the Romanian and foreign researcher does not take place predominantly in the professional space of the 'foreigners', but in the familiar national space of the autochthonous researcher. Second, the relationship with those who devoted themselves to fieldwork in Romania unfolded in terms of cooperation, rather than some kind of paternalistic hegemony. The above-mentioned researchers, through the very nature of their profession, did not come to Romania to teach lessons, but rather to understand, throughout a process of learning in which the roles are often interchangeable, which creates a two way road between those who teach and those who learn. The Romanian researchers become subjects, key informants, and research partners. This group that includes Gail Kligman has the merit of recording responsibly and of treating their sources of autochthonous knowledge honestly and non-exploitatively. Through co-opting Romanians in their research teams, they also contributed to the reconstruction of sociology and anthropology as professional fields, self-sustaining and with autonomous working principles. It is one of the roads towards de-periferialization that is open for the current young generations of researchers.

It is time, therefore, to festively declare Gail Kligman 'one of us': this is how many of us, reunited here today, have felt about her, through reading and using her books in our own research, in debates with our students and the wider public, in our teaching, in our own trajectories as intellectuals. She is 'ours' in many ways, the most important of which I have already mentioned. And this awarding of the title of Doctor Honoris Causa to Professor Gail Kligman is but a belated yet welcome ritual through which us, the academic community of Cluj, acknowledge the excellence of her intellectual work and state our intellectual affinities with her. It is a form of assuming a fictive kinship, somewhat similar to that assumed by her adoptive family in Maramureș long before us, decades ago. Her presence here for this ceremony also marks our symbolic reappropriation of the communities studied by Gail Kligman. They used to be exotic to many of us, out of lack of interest or cultural difference, but the work of the researcher has turned the nearby 'stranger' into a familiar figure. Through her research interests and due to the way in which she has devoted much of her career and much of her life to understanding Romanian communities, Gail Kligman has become 'Romanian', while remaining 'very much American', to paraphrase a famous quote.

Allow me to explain myself.

The Romanians preoccupied by 'the image of the country in the world' are at the same time sensitive to the way in which the problems in Romania are depicted by the researchers in Europe or the United States. This image from the outside does not often coincide with the one we like to contemplate ourselves. 
Moreover, what we observe about the world we belong to often differs from what outsiders observe. The distinction between 'autochthon' and 'foreigner' is therefore more likely to be translated into the difference between the perception of the insider and that of the outsider from the point of view of the reality under the lens. That is to say, we are looking at the distinction between emic and etic. In stating this, I am clearly oversimplifying. In fact, there is no generalized 'us' that can be looked at as unitary and homogenous - except as an idealized version of reality or as a rhetoric artifice - any more than there is no equally generic 'other' except as a fiction fed by the mirage of our own desires, as it might be the case for those who live in Eastern Europe with a certain view of the West.

These distinctions operate through the means of opposing the novel and the surprising, that which is different from our habitual routines, to what appears unworthy of observation, banal and taken for granted. Indeed, we only investigate and depict what seems to be significant, what makes us exclaim 'look at that!' when we interact with others. And this 'look at that!' along with the entire intellectual construction organized around this wonder, also differs with the person we address, whether they are internal or external to that reality. Therefore, in the international circuit of presenting the Romanian issues, there are four ways of addressing them: that of the 'foreigner' who writes about us for 'their own people', also 'foreigners'; that of the 'foreigner' who writes about us for 'our own people', 'the autochthonous'; that of 'the autochthonous' who writes for 'the foreigners', and that of 'the autochthonous' who writes for 'the autochthonous' - and all of these models have their own discursive constraints and assemble multiple lenses for reading and interpreting for the various audiences.

For instance, the 'foreigner' describing Romania does so according to the needs of the readers in their country of origin. In fact, they operate a 'cultural translation' that needs to resort to general information and to make explicit contexts that are taken for granted by the Romanian reader. By contrast, the puzzlement of 'the foreigner' and the local realities that capture their attention will reveal themselves as 'exotic' to the 'autochthonous', who will turn their gaze upon them for the first time and ask themselves: 'why is it that this common thing has captured the attention of the foreigner?'

Altered by the revelation of the unusual, 'the autochthonous' will be able to reevaluate their own familiarity as somewhat alien, and will reappropriate it from a fresh angle, generated by the gaze of the other. Yet, when addressing the public as an author, 'the autochthonous' will leave aside the overly familiar aspects they consider to be trivial. And when 'the autochthonous' will address an audience of outsiders, they will tend to make their own selection of what they believe is worth disclosing, sometimes to effects of confusion and boredom on the behalf of the foreign audience.

All these interplays of familiarization and de-familiarization with the reality under investigation can flip once again over the course of fieldwork. This is 
because there are circumstances where 'the foreigner' in the field is more autochthonous than the 'autochthonous' sociologist that, from their office and from behind their computer, misses the mark in describing the concrete reality. What defines first and foremost the closeness with the communities under study is the degree of professionalism in conducting the research. As Bourdieu put it, it is one thing to live in a place and quite another to know it. Belonging does not imply competence and the quality of being 'autochthonous' is not the basis of taken for granted knowledge. In the terms of the professional coordinates of the social sciences, then, the relationship between 'us' and 'them' is redefined in accordance with epistemological, rather than domestic familiarity, that is to say, it is set by in-depth knowledge and acquaintanceship with the structural, long term aspects of the objects of the research. From this point of view, Gail Kligman's research has turned her into a person who is 'autochthonous' to a much greater degree than many local researchers.

But perhaps the most important argument about this 'indigenization' of the researcher comes from their ability to follow their own reflexive streak. Those who find themselves alone in the field develop an ability to think independently, as well as their own way to reflect on the social world. They do a lot more than apply set rules for social research. The incorporation of their own experience, on top of the experience of the informants in field, is the key to establishing one's own way to understand a world into which they landed through the bureaucratic backstage of an academic enterprise doubled by a research project. The solitude of fieldwork leaves just the opportunity to reinvent oneself, while at the same time reinventing the discipline to which one contributes - just like Malinowski did, abandoned for the length of World War I to do field research of an uncertain duration, facing uncertain challenges.

The anthropologist is therefore a voluntary Robinson: the shipwreck is deliberate, the familiarization with the island and its particular conditions for survival is mandatory. They are part of the job description. Fieldwork is an opportunity for reconstructing the self of the anthropologist in relation with an 'other' presumed from the beginning to be unknown.

In our turn, us, the 'autochthonous', have somehow travelled the same road in the opposite direction: we have gotten closer to the anthropologist, assuming some of their thinking and thus becoming a little bit like 'them'. We have read their books, followed their advice, and learnt the tough lessons from the field research. The distance between 'us' and 'other' is therefore reduced as we manage to recognize ourselves in the other. The celebration today aims to mark our finding our way back to each other. 